\title{
KONSISTENSI KINERJA KADER JUMANTIK TERHADAP PREVALENSI DBD DI KABUPATEN REJANG LEBONG TAHUN 2014
}

\author{
Rustam Aji, Jon Farizal, Rini Patroni \\ Politeknik Kesehatan Kementerian Kesehatan Bengkulu, Jurusan Keperawatan, \\ Jalan Indragiri Nomor 3 Padang Harapan Bengkulu \\ adjieroestamadjie@rocketmail.com
}

\begin{abstract}
Abstrak : Penyakit DBD jenis penyakit menular disebabkan Penyakit demam berdarah dengue yang penyebarannya sangat cepat dan sering menimbulkan kejadian luar biasa (KLB) di masyarakat, sehingga menimbulkan angka kesakitan dan kematian. Dalam mencegah DBD di perlukan konsistensi kinerja dari kader jumantik di Kabupaten Rejang Lebong. Tujuan penelitian ini adalah untuk mengetahui hubungan konsistensi kinerja kader jumantik terhadap prevalensi DBD di Kabupaten Rejang Lebong Tahun 2014. Metode penelitian menggunakan design deskriptif analitik, pendekatan cross sectional dengan total sampel berjumlah 40 responden. Pengumpulan data menggunakan kuisioner dan menggunakan uji statistik bivariat Chi-Square. Hasil keseluruhan bahwa sebagian besar dari 25 responden (62,5\%) mempunyai konsistensi kinerja kader jumantik baik terhadap Prevalensi DBD tinggi. Berdasarkan analisis Chi-square diperoleh nilai P : 0,000, ini berarti bahwa nilai $\mathrm{p}$ value $0,000<$ nilai $\alpha=0,05$ maka Ho ditolak dan Ha di terima yang berarti secara statistik ada hubungan yang signifikan antara konsistensi kinerja kader jumantik terhadap prevalensi DBD, dimana nilai OR : 1.000 , berarti prevalensi DBD tinggi maka responden terlindungi sebanyak 1.000 kali lebih dibandingkan dengan konsistensi kinerja kader jumantik yang kurang. Disarankan pembinaan, penyegaran terhadap petugas kader jumantik yang mengabdi secara sukarela, serta pemberian insentif (reward) dari Puskesmas maupun Dinas Kesehatan.
\end{abstract}

Kata kunci: Konsistensi Kinerja Kader Jumantik, Prevalensi DBD.

Abstract : Dengue fever infectious diseases caused dengue fever is spreading fast and often lead to extraordinary events (KLB) in the community, causing morbidity and mortality, to prevent dengue in need consistency in the performance of cadres larva monitoring in Rejang Lebong. The aim of this research was to determine the relationship consistency larva monitoring cadre performance against the prevalence of dengue in Rejang Lebong 2014. The methods of this research was descriptive analytic design with cross sectional approach and total sample were 40 respondents. Data collection using questionnaires and bivariate statistical test Chi-Square. The overall result that most of the 25 respondents $(62.5 \%)$ had a good consistency jumantik cadre performance against high prevalence of dengue fever. Based on Chi-square analysis was obtained values P: 0,000 , this means that the $\mathrm{p}$ value $0.000<$ value $\alpha=0.05$, then Ho is rejected and Ha accepted which means no statistically significant relationship between the consistency of the performance of larva monitoring cadres to the prevalence of dengue, which value OR: 1.000, mean high prevalence of dengue fever, the respondents are protected as much as 1,000 times more than the consistency of performance of larva monitoring cadres were lacking. It suggested to make development, a refresher on larva monitoring cadre officers who serve voluntarily, as well as the provision of incentives (rewards) of the Health Center and the Department of Health.

Keywords: Performance Consistency Jumantik Kader, prevalence of dengue.

Penyakit demam berdarah dengue (DBD) dimasyarakat merupakan salah satu jenis penyakit menular akut yang masih menjadi masalah kesehatan baik individu, keluarga maupun masyarakat. Hal ini disebabkan Penyakit demam berdarah dengue penyebarannya sangat cepat dan sering menimbulkan kejadian luar biasa (KLB) di masyarakat, sehingga menimbulkan angka kesakitan dan kematian.Demam berdarah dengue adalah penyakit febris virus akut, yang ditularkan melalui gigitan nyamuk aedes aegypti dari nyamuk yang menularkan virus dengue ke tubuh manusia melalui air liurnya yang masuk kealiran darah sehingga menimbulkan penyakit demam berdarah dengue. WHO (2004). 
Kementerian Kesehatan beserta jajarannya membuat strategi utama pemberantasan DBD dalam memberantas nyamuk dewasa melalui pengasapan (fogging), kemudian strategi diperluas dengan menggunakan larvasida yang ditaburkan ke tempat penam-pungan air (TPA). Kedua metode tersebut sampai sekarang belum memperlihatkan hasil yang memuaskan. Terbukti, dari jumlah kasus DBD meningkat dan jumlah wilayah yang terjangkit DBD (Kemenkes RI, 2013).

Berbagai upaya telah dilakukan untuk mencegah terjadinya penularan penyakit DBD di masyarakat. Untuk mencapai tujuan ini, pengendalian kepadatan populasi vektor DBD mendapat perhatian yang besar. Cara yang paling efektif dalam pengendalian populasi larva dan vektor DBD adalah dengan pengentasan lingkungan, yang selama ini dikenal dengan Gerakan Serentak Pemberantasan Sarang Nyamuk (Gertak PSN), diharapkan akan mengurangi kepadatan populasi larva dan vektor DBD (Kemenkes RI, 2013).

Penyebaran penyakit DBD di Indonesia pertama kali ditemukan di Kota Surabaya di provinsi Jawa Timur pada tahun 1968, virus DBD ditemukan tahun 1972, penyakit DBD mulai menyebar keberbagai daerah dan provinsi di Indonesia, sehingga pada tahun 1980 seluruh provinsi di Indonesia telah terjangkit penyakit DBD.

Negara Indonesia merupakan wilayah endemis dengan sebaran angka prevalensi kasus DBD diseluruh wilayah tanah air, pada tahun 2008 tercatat 117.830 kasus dengan 953 kematian, pada tahun 2010 tercatat 156.086 kasus dengan 1.358 kematian, menempati urutan tertinggi kasus DBD di Asean, dan pada tahun 2011 kasus DBD di Indonesia menurun dengan jumlah kasus 49.486 dan jumlah kematian 403 orang. Dit Jen PP dan PL Kementerian Kesehatan RI (2012).

Kabupaten Rejang Lebong dengan luas wilayah $1.515 .76 \mathrm{~km}^{2}$ terdiri dari 122 desa dan 34 kelurahan dalam 15 jumlah penduduk 250,608 jiwa, kepadatan penduduk 165 per $\mathrm{km}^{2}$ (Dinkes Kabupaten Rejang Lebong, 2012).
Berdasarkan Laporan Tahunan Dinas Kesehatan Provinsi Bengkulu di empat kabupa-ten angka prevalensi DBD ada 157 kasus DBD dalam tahun 2011, terdiri dari Kabu-paten Rejang Lebong 66 ada kasus DBD, Bengkulu Selatan tahun 2011 ada 51 kasus DBD, Bengkulu Tengah tahun 2011 ada 24 kasus DBD, Kepahiang tahun 2011 ada 16 kasus DBD. Laporan Dinas Kesehatan Propinsi Bengkulu (2012).

Penderita DBD di Puskesmas Perumnas Curup Kabupaten Rejang Lebong berdasar-kan data suspect DBD yang di peroleh dari laporan profil kesehatan Kabupaten Rejang Lebong dari tahun 2006 ada 7 orang, tahun 2007 ada 52 orang, tahun 2008 ada 79 orang, tahun 2009 ada 57 orang, tahun 2010 ada 16 orang, tahun 2011ada 19 orang, tahun 2012 ada 66 orang dan tahun 2013 ada 28 orang, jumlah suspect DBD selama 8 tahun ada 324 orang dengan suspect DBD. Berdasarkan laporan profil Dinas Kesehatan Kabupaten Rejang Lebong (tahun 2006 sampai dengan tahun 2013).

Petugas juru pemantau jentik DBD di desa/kelurahan pada 10 (sepuluh) Kabupaten Di Wilayah Provinsi Bengkulu pada tahun 2012, terdiri dari 1). Kabupaten Muko-Muko ada 8 petugas juru pemantau jentik, 2). Kabupaten Kaur ada 8 petugas juru pemantau jentik, 3). Kabupaten Bengkulu Utara ada 9 petugas juru pemantau jentik, 4). Kabupaten Bengkulu Tengah ada 8 petugas juru peman-tau jentik, 5). Kabupaten Bengkulu Selatan ada 9 petugas juru pemantau jentik, 6). Kabu-paten Rejang Lebong ada 8 petugas juru pe-mantau jentik, 7). Kabupaten Seluma ada 8 petugas juru pemantau jentik, 8). Kabupaten Lebong ada 8 petugas juru pemantau jentik, 9). Kabupaten Kepahiang ada 8 petugas juru pemantau jentik, 10). Kota Bengkulu ada 8 petugas juru pemantau jentik, jumlah keselu-ruhan ada 58 orang petugas juru pemantau jentik DBD di Desa / kelurahan di 10 Kabupaten dalam wilayah Provinsi Bengkulu. Laporan Dinas Kesehatan Propinsi Bengkulu (2012).

Peneliti mengambil konsistensi kinerja kader juru pemantau jentik (jumantik) di Kabupaten Rejang lebong berjumlah 40 orang 
kader jumantik (Dinkes Kabupaten Rejang Lebong 2014).

Penomena versi masyarakat dulu pada waktu awal-awal dibentuk petugas kader jumantik, konsistensi kinerja petugasnya rajin sekali sebulan dua kali mengecek TPA di rumah-rumah masyarakat daerah binaannya, selain itu petugas kader jumantik membagikan leaflet dan bubuk abate, bila ada kasus DBD petugas kader jumantik melapor ke Puskesmas dan Dinas Kesehatan, bersama petugas dari Puskesmas dan Dinas Kesehatan melakukan penyemprotan dengan pengasapan (fogging) di RT dan RW yang sedang terkena wabah kasus DBD.

Masyarakat di di Kecamatan Curup Kota, Curup Tengah, Curup Selatan, mengeluhkan kinerja para petugas kader jumantik yang pernah dilatih, mereka tidak maksimal untuk mendatangi dan mengecek TPA dipemukiman warga, masyarakat mengeluhkan beberapa tidak ada petugas kader jumantik yang datang ke rumah-rumah warga maupun lingkungan dimasyarakat apalagi membagikan bubuk abate tidak pernah diberikan padahal pemukiman padat yang rentan terhadap berkembangnya jentik nyamuk Aedes aegypti. walaupun ada warga terkena DBD.

Peneliti juga mencari informasi dari para petugas kader jumantik yang pernah dilatih binaan dari Dinas Kesehatan Provinsi Bengkulu, sebagian dari para petugas kader jumantik yang berhasil peneliti temui, mereka para petugas kader jumantik mengeluhkan waktu diawal pelatihan mereka mendapatkan honor satu kali saat pelatihan menjadi petugas kader jumantik di Dinas Kesehatan Provinsi Bengkulu.

Setelah mereka kembali di masyarakat honor tidak pernah mereka dapatkan, pembinaan dan bimbingan berupa penyegaran dari Dinas Kesehatan Kabupaten Rejang Lebong tidak pernah didapatkan, jadi semangat untuk bekerja sudah tidak ada, harapan dari petugas jumantik agar pemerintah daerah menyediakan anggaran honor khusus bagi petugas kader jumantik yang bersumber dari APBD dan warga masyarakat dapat menumbuhkan kesadaran sendiri untuk menjaga kebersihan lingkungan TPA dirumah masing-masing

Utamanya pada daerah perkotaan yang masyarakatnya cukup padat dan mobilitas tinggi. Peneliti berpendapat penyegaran, pembinaan dan pembentukan regenerasi pada petugas kader jumantik dengan tenaga khusus dianggarkan gajinya setiap bulannya,sehingga program pemantauan dan pemberantasan jentik nyamuk dapat dijalankan oleh petugas kader jumantik, sehingga dapat menekan kasus DBD dan lingkungan bebas jentik nyamuk.

Perilaku masyarakat yang diharapkan proaktif dalam memelihara dan meningkatkan derajat kesehatan, mencegah terjadinya resiko penyakit, melindungi diri dari ancaman penyakit, serta berpartisipasi aktif dalam gerakan peningkatan kesehatan masyarakat melalui promosi kesehatan. Meningkatkan peran aktif masyarakat dan anggota keluarga dalam pencegahan dan penanggulangan penyakit DBD merupakan kunci keberhasilan upaya pemberantasan penyakit DBD. Tujuan penelitian ini adalah untuk mengetahui hubungan konsistensi kinerja kader jumantik terhadap prevalensi DBD di Kabupaten Rejang Lebong Tahun 2014.

\section{BAHAN DAN CARA KERJA}

Penelitian dilaksanakan di Kabupaten Rejang Lebong. Pengambilan data dan pengolahan data dilaksanakan dari bulan April sampai bulan Desember 2014. Sampel diambil secara total sampling sebanyak 40 kader jumantik sebagai responden. Jenis penelitian ini merupakan penelitian deskriptif dengan pendekatan Cross sectional. Variabel Penelitian meliputi survei pada karakteristik responden (umur, jenis kelamin, pendidikan, pekerjaan, lama bekerja sebagai kader jumantik). Variabel terikat adalah prevalensi DBD. Teknik pengumpulan data dilakukan melalui pembagian dan pengisian pada lembar kuesioner pada responden untuk mendapatkan data karakteristisk identitas responden yang meliputi umur, jenis kelamin, pendidikan, 
pekerjaan, lamanya kerja sebagai petugas kader jumantik

\section{HASIL}

\section{Analisis Univariat}

Tabel 1. Distribusi Frekuensi Karakteristik Responden

\begin{tabular}{lcc}
\hline \multicolumn{1}{c}{ Karakteristik } & Frekuensi & Persentase (\%) \\
\hline Umur & & \\
$<35$ tahun & 20 & $50 \%$ \\
$>35$ tahun & 20 & $50 \%$ \\
Jenis Kelamin & & \\
$\quad$ Laki-laki & 22 & $55 \%$ \\
$\quad$ Perempuan & 18 & $45 \%$ \\
Pendidikan & & \\
SD & 6 & $15 \%$ \\
SMP & 16 & $40 \%$ \\
SMA & 14 & $35 \%$ \\
D.3 & 2 & $5 \%$ \\
S.1 & 2 & $5 \%$ \\
Pekerjaan & & \\
PNS & 8 & $20 \%$ \\
Swasta & 11 & $27.5 \%$ \\
Petani & 3 & $7.5 \%$ \\
Tukang & 2 & $5 \%$ \\
Pedagang & 12 & $30 \%$ \\
Buruh & 4 & $10 \%$ \\
Lama Kerja sebagai Kader Jumantik & \\
Diatas 1 tahun & 33 & $82.5 \%$ \\
Dibawah 1 tahun & 7 & $17.5 \%$ \\
Konsistensi Kinerja Kader & \\
Jumantik terhadap Prevalensi DBD & \\
Baik & 25 & $62.5 \%$ \\
Kurang & 15 & $37.5 \%$ \\
\hline
\end{tabular}

Pada tabel 1 diketahui bahwa karak-teristik setengah dari 20 responden $(50 \%)$ berumur dibawah 35 tahun, sebagian besar da-ri 22 responden (55\%) laki-laki, hampir seba-gian dari 16 responden (40\%) berpendidikan SMP, hampir sebagian dari 12 responden (30\%) bekerja sebagai pedagang, hampir seluruh dari 33 responden $(82,5 \%)$ lama kerja sebagai petugas kader jumantik didibawah 1 tahun. Sebagian besar dari 25 responden (62.5\%) mempunyai konsistensi kinerja kader jumantik terhadap prevalensi DBD.

\section{Analisis Bivariat}

Berdasarkan Tabel 2 diperoleh hasil bahwa sebagian kecil dari 6 responden (15\%) konsistensi kinerja kader jumantiknya kurang menyebabkan Prevalensi DBD Rendah, dan hasil lain bahwa sebagian kecil dari 9 responden $(22,5 \%)$ walau konsistensi kinerja kader jumantiknya kurang terhadap Preva-lensi DBD, kasus DBD tinggi, sementara disisi lain bahwa sebagian kecil dari 10 responden $(25 \%)$ konsistensi kinerja kader jumantiknya baik akan tetapi Prevalensi DBD menjadi tinggi dan hasilnya bahwa hampir sebagian kecil dari 15 responden $(37,5 \%)$ konsistensi kinerja kader jumantik baik, Prevalensi DBD tinggi, hasil keseluruhan bahwa sebagian besar dari 25 responden $(62,5 \%)$ mempunyai konsistensi kinerja kader jumantiknya baik terhadap Prevalensi DBD tinggi.

Berdasarkan analisis Chi-square diperoleh nilai $\mathrm{p}: 0,000$, ini berarti bahwa nilai $\mathrm{p}$ value $0,000<$ nilai $\alpha=0,05$ maka Ho ditolak dan Ha di terima yang berarti secara statistik ada hubungan yang signifikan antara konsistensi kinerja kader jumantik terhadap prevalensi DBD, dimana nilai OR : 1.000 , berarti prevalensi DBD tinggi maka responden terlindungi sebanyak 1.000 kali lebih dibandingkan dengan konsistensi kinerja kader jumantik yang kurang.

\section{PEMBAHASAN}

Dari hasil penelitian diperoleh ada hubungan yang signifikan antara konsistensi kinerja kader jumantik terhadap prevalensi DBD, sejalan dengan hasil penelitian Ni Putu Desy Arisandi (2013). Simpulan dari peneli-tiannya bahwa yang memiliki pengaruh signifikan terhadap kinerja jumantik yaitu variabel kinerja supervisi. Bertentangan dengan hasil penelitian Arta Sapta Rini, dkk (2011) bahwa Pemberdayaan kader Ibu Pemantau Jentik (Bumantik) tidak ada hu-bungan dengan nilai Angka Bebas Jentik (ABJ), Container Index (CI) dan 3M Plus. Sependapat dengan hasil penelitian Ni Putu Desi Arisandi (2013), hasil penelitiannya menyatakan bahwa 105 orang jumantik dengan 11 koordinator jumantik Rendahnya ABJ di Kecamatan Denpasar Selatan < 95\% mengindikasikan rendahnya kinerja jumantik dalam pelaksanaan PSN belum maksimal. 
Tabel 2. Hubungan Konsistensi Kinerja Kader Jumantik Terhadap Prevalensi DBD di Kabupaten Rejang Lebong Tahun 2014

\begin{tabular}{|c|c|c|c|c|c|c|c|c|c|c|}
\hline \multirow{3}{*}{$\begin{array}{c}\text { Konsistensi Kinerja } \\
\text { Kader Jumantik }\end{array}$} & \multicolumn{4}{|c|}{ Prevalensi DBD } & \multirow{2}{*}{\multicolumn{2}{|c|}{ Total }} & \multirow{3}{*}{$\mathbf{P}$} & \multirow{3}{*}{$\begin{array}{c}\text { OR } \\
(95 \%)\end{array}$} & \multirow{2}{*}{\multicolumn{2}{|c|}{ CI }} \\
\hline & \multicolumn{2}{|c|}{ DBD Rendah } & \multicolumn{2}{|c|}{ DBD Tinggi } & & & & & & \\
\hline & $\mathbf{f}$ & $\%$ & $\mathbf{f}$ & $\%$ & f & $\%$ & & & Lower & Upper \\
\hline Kurang & 6 & 15 & 9 & 22,5 & 15 & 37,5 & 0,000 & 1.000 & 0,271 & 3,694 \\
\hline Baik & 10 & 25 & 15 & 37,5 & 25 & 62,5 & & & & \\
\hline Total & 16 & 37.5 & 24 & 62,5 & 40 & 100 & & & & \\
\hline
\end{tabular}

Terdapat tiga fakor yang mempengaruhi kinerja seseorang yaitu faktor individu, psikologis, dan organisasi Motivasi merupa-kan salah satu faktor psikologis yang mempengaruhi kinerja jumantik Motivasi dibagi menjadi dua yaitu motivasi internal dan motivasi ekternal.

Sependapat dengan hasil penelitian Yuristisia (2012) Hasil penelitiannya bahwa keberhasilan implementasi kebijakan dipengaruhi oleh faktor komunikasi, sumber daya, disposisi dan struktur birokrasi. Oleh sebab itu, untuk mencegah DBD diperlukan kesinambungan pelaksanaan program secara rutin oleh semua pihak Kata Kunci: implementasi kebijakan, pengendalian DBD.

Sejalan dengan hasil penelitian Rizki Mubarokah (2012) hasil penelitiannya bahwa Hasil ada perbedaan yang bermakna ABJ DBD antara sebelum dan sesudah pergerakan jumantik dengan $\mathrm{p}$ value $(0,000)<\alpha(0,005)$. Simpulan : Pergerakan jumantik dapat meningkatkan ABJ DBD di RW I Kelurahan Danyang Kecamatan Purwodadi Kabupaten Grobogan. Simpulan peneliti bahwa motivasi dari dalam maupun luar yang baik akan menimbulkan dampak positif dan negatif bagi seseorang, tergantung maknanya baik atau buruk.

\section{DAFTAR RUJUKAN}

Arta Sapta Rini, Ferry Efendi \& Eka Misbahatul M Has. 2011. Hubungan Pemberdayaan Ibu Pemantau Jentik (Bumantik) dengan Indikator Keberhasilan Pemberantasan Sarang Nyamuk (PSN) di Kelurahan Wonokromo. Surabaya:

Dit Jen PP dan PL Kementerian Kesehatan RI (2012). Penanggulangan Penyakit DBD melalui Kerjasama dengan Kader Juru Pemantau Jentik. Jakarta:

\section{KESIMPULAN}

Karakteristik umur setengah responden berumur dibawah 35 tahun, sebagian besar dari responden adalah laki-laki, hampir sebagian dari responden berpendidikan SMP, hampir sebagian dari responden bekerja sebagai pedagang, hampir seluruh dari responden lama kerja sebagai petugas kader jumantik dibawah 1 tahun. Secara statistik ada hubungan yang signifikan antara konsis-tensi kinerja kader jumantik terhadap preva-lensi DBD, prevalensi DBD tinggi maka res-ponden terlindungi sebanyak 1.000 kali lebih dibandingkan dengan konsistensi kinerja kader jumantik yang kurang.

Bagi Dinas Kesehatan Agar dapat memberikan pembinaan penyegaran kepada petugas kader jumantik. Peneliti berharap petugas kader jumantik, dapat meningkatkan perilaku dan kinerja kader jumantik serta peduli terhadap pencegahan DBD di lingkung-an masyarakatnya. Program jumantik cukup berperan dalam memantau kondisi lingkungan masyarakat dan selanjutnya memberikan edukasi yang baik, harus ada petugas khusus yang bergerak untuk bekerja ekstra dalam upaya pencegahan DBD.

Pengendalian Penyakit dan Penyehatan Lingkungan.

Dinas Kesehatan Kabupaten Rejang Lebong. 2012. Laporan Tahunan Geografi dan Kesehatan. Rejang Lebong: Dinas Kesehatan Kabupaten Rejang Lebong Curup. 
Dinas Kesehatan Propinsi Bengkulu (2012). Profil Kesehatan Dinas Kesehatan Provinsi Bengkulu. Bengkulu: Kabid P2M.

Dinas Kesehatan Kabupaten Rejang Lebong. 2014. Laporan Kepala Bidang Program Pencegahan dan Pengendalian Penyakit Menular Dinas Kesehatan Kabupaten Rejang Lebong. Rejang Lebong:

Dinas Kesehatan Kabupaten Rejang Lebong. 2013. Laporan Kantor Statistik Kabupaten Rejang Lebong dalam Profil Kesehatan Kabupaten Rejang Lebong.

Kementerian Kesehatan RI. 2013. Demam Berdarah Dengue. Buletin Jendela Epidemiologi, volume 2 Agustus 2010. Pusat Data dan Surveilens Epidemiologi.

Marista Octaviani Tanjung. 2012. Perilaku Kader Jumantik dalam Melaksanakan PSN DBD 3M Plus di Kelurahan Jomblang Kecamatan Candisari.

Sumarmo. 2005. Epidemiologi Lingkungan. Yogyakarta: Gadjahmada University.

Notoatmodjo. 2009. Konsep Dasar Perilaku dan Promosi Kesehatan. Jakarta: Rineka Cipta.

Nursalam. 2003. Konsep dan Penerapan Metodologi Penelitian Keperawatan.

Notoatmodjo. 2009. Konsep Dasar Perilaku dan Promosi Kesehatan. Jakarta: Rineka Cipta.
Nursalam. 2003. Konsep dan Penerapan Metodologi Penelitian Keperawatan Jakarta: Salemba Medika.

Ni Putu Desi Ary Sandhi. 2013. Pengaruh Faktor Motivasi Terhadap Kinerja Juru Pemantau Jentik dalam Pelaksanaan PSN di Kecamatan Denpasar Selatan

Rizqi Mubarokah. 2012. Upaya Peningkatan Angka Bebas Jentik DBD melalui pergerakan Juru Pemantau Jentik (Jumantik) di RW I Kelurahan Danyang Kecamatan Purwodadi Kabupaten Grobogan.

Sri Suharti. R. 2010. Hubungan Pengetahuan dan Motivasi dengan Perilaku Kepala Keluarga dalam Pemberantasan PSN-DBD di Wilayah Kerja Puskesmas Loa Ipuh Kabupaten Kutai Karta Negara.

WHO. 2004. Panduan lengkap pencegahan dan pengendalian dengue dan demam berdarah dengue. Jakarta: EGC.

Yuristisia, Harinda Wina. 2012. Analisis Implementasi Kebijakan Pengendalian Demam Berdarah Dengue Pada Kader Juru Pemantau Jentik Di Wilayah Kelurahan Sendangmulyo Kecamatan Tembalang Kota

Semarang. 